\title{
Comparison of decision making skills and self-efficacy perception levels in adolescents in terms of gender and grade variables
}

\author{
Aslı SARIŞAN-TUNGAÇ* \\ Mathematics and Science Education Department, Ondokuz Mayis University, Samsun, \\ Turkey, https://orcid.org/0000-0003-3709-5288 \\ Süleyman YAMAN \\ Mathematics and Science Education Department, Ondokuz Mayis University, Samsun, \\ Turkey, https://orcid.org/0000-0001-5152-4945
}

\section{Belgin BAL-İNCEBACAK}

Primary Education Department, Ondokuz Mayis University, Samsun, Turkey, https://orcid.org/0000-0003-4643-8051

\begin{tabular}{|c|c|}
\hline Article history & In this study it is aimed to reveal the relationship between secondary \\
\hline $\begin{array}{l}\text { Received: } \\
28.02 .2020\end{array}$ & $\begin{array}{l}\text { school students' decision-making skills in adolescence and their self- } \\
\text { efficacy perceptions regarding science learning. The sample of the }\end{array}$ \\
\hline $\begin{array}{l}\text { Received in revised form: } \\
26.04 .2020\end{array}$ & $\begin{array}{l}\text { study consists of a total of } 564 \text { students from six public schools located } \\
\text { in four city centers in the Central Black Sea Region. } 251 \text { of these } \\
\text { students are female and } 313 \text { are male. The research was carried out }\end{array}$ \\
\hline $\begin{array}{l}\text { Accepted: } \\
30.04 .2020\end{array}$ & $\begin{array}{l}\text { with the descriptive survey model. As the data collection tools, Self- } \\
\text { Efficacy Perception scale regarding Science Learning (SEPRSL) and }\end{array}$ \\
\hline Key words: & the Adolescent Decision Making Scale (ADMS) are resorted to. The \\
\hline $\begin{array}{l}\text { Science education, } \\
\text { self-efficacy belief, } \\
\text { decision making, } \\
\text { secondary school }\end{array}$ & $\begin{array}{l}\text { When the self-efficacy scores are examined depending on gender, it is } \\
\text { found that the self-efficacy belief levels of female students are higher } \\
\text { than male students, yet not significantly. Also, students have decision- } \\
\text { making skills below the average level. When the results of the study are } \\
\text { evaluated in general, it is determined that there is a relationship } \\
\text { between self-efficacy perception for science learning and adolescent } \\
\text { decision-making skills, and when evaluated in terms of gender, there is } \\
\text { generally a difference in favor of female students. Based on these } \\
\text { results, it can be said that it will be useful to produce and implement } \\
\text { projects that include activities in which students will use their decision- } \\
\text { making skills in order to increase their self-efficacy perceptions of } \\
\text { science learning. }\end{array}$ \\
\hline
\end{tabular}

\section{Introduction}

Physical Science is a branch of science that emerges from the attempt to make sense of the events that take place in their environment with the effects of people or that spontaneously exist in nature (Kaptan, 1999). In this discipline, information is structured by

\footnotetext{
*Correspondence: aslisarisan@gmail.com
} 
passing through stages called scientific process skills (Tan \& Temiz, 2003). Observation, which is one of the scientific process skills, starts in fact with the opening of the eyes to the world. Therefore, it can be articulated that physical science education is a process that continues from birth to death. This process can either be formal or informal. The main aim of formal physical science education is to raise individuals as physical science literate (Ministry of Education [MNE], 2018).

Science literacy, with its most general definition, is a combination of science-related skills, attitudes, values, understandings and knowledge necessary for individuals to develop their research-inquiry, critical thinking, problem-solving and decision-making skills, to continue lifelong learning, and to maintain their curiosity about the world around them (Feinstein, 2010; Kavak, Tufan, \& Demirelli, 2006; Norris \& Philips, 2003). Based on this definition, it can be uttered that cognitive, affective and psychomotor dimensions play a critical role in gaining physical science literacy. Considering that these dimensions are not independent from each other in the learning process, the relationship between them is indeed important. There are a fair number of skills and behaviors under each dimension of these learning. Self-efficacy skill is in the affective domain dimension; Decision making skills are among the skills that cover both affective and cognitive skills.

Self-efficacy belief was first introduced into the literature by Bandura (1997) as the key concept of Social Cognitive Learning theory. Bandura expressed this concept as the perception of self-efficacy that individuals hold as to how much of the knowledge and skills they are able to use/need to use to successfully overcome any situation they face. Selfefficacy belief is a perception of competence that leads individuals to seek the source of the problem in situations such as failure, as well as providing the development of success, attitude, knowledge and skills (Yıldırım \& İlhan, 2010). According to Ergül (2006), selfefficacy belief is an effective determinant in success and plays an important role in the change of behavior. It is known that individuals with high self-efficacy beliefs are more successful in problem solving (Altunçekiç, Yaman, \& Koray, 2005). Caymaz (2008) examined the selfefficacy belief in terms of physical science literacy and interpreted this concept as an individual's beliefs in their level of having the necessary knowledge, skills, attitude regarding science learning. According to Saracaloğlu, Yenice, \& Özden (2013), individuals who have this information are capable of making more conscious decisions. Thus, it will be possible for individuals who are physical science literate to use their decision making skills effectively in solving the problems they encounter in daily life.

Decision making skills of students are an effective factor in the learning process (Avşaroğlu \& Üre, 2007). In many studies decision making is defined as choosing one of the most suitable possibilities under existing conditions (Beyth-Marom, Fischoff, Jacobs Quadrel, \& Furby, 1991; Emhan, 2007; Furby \& Beyth-Marom, 1992; Von Winterfeldt \& Edwards, 1986). This behavior is an activity that starts with the realization of a situation to be decided on and is completed by determining when and how the individual decides against this situation (Alver, 2005). Norfolk (1989) emphasizes that individuals often face complex decision-making situations in daily life. The decisions made in this process differ according to the conditions, environmental factors and personal development levels. In particular in adolescence, decision-making skills are known to have important effects on personality development (Çolakkadığlu, 2012). As a matter of fact, decision making is one of the factors that also affect self-efficacy (Deniz, 2004; Narangerel, 2020; Titrek, Konak, \& Titrek, 2013). Forbes (2005) stated in his study that decision-making skill makes a significant difference on entrepreneurial self-efficacy. The studies in which decision-making and self-efficacy beliefs 
are handled together are predominantly studies with career decision-making self-efficacy scales (Betz, Klein, \& Taylor, 1996). In these studies, the extent to which the levels of selfefficacy beliefs changed decision making for the future of the relevant participants are examined. In this study, it is aimed to investigate the relationship between secondary school students' decision making processes and their sub-dimensions and their self-efficacy towards science learning. It is considered that this research will contribute to the related literature since not many studies are witnessed where these related skills are discussed in a united fashion.

\section{Method}

In the research, descriptive survey method was applied to determine the self-efficacy perceptions of the participants and their decision making skills in adolescence. The aim in the descriptive research model is to reveal the features examined as they exist (Karasar, 2012). In this study, the opinions of the participant students were determined by one-time assessments with graded scales and no intervention was made whilst getting the opinions of the participant students.

\section{Sample}

The sample of the study consists of a total of 590 students from six public schools located in four city centers in the Central Black Sea Region. Since the data of 26 of these students are not included in the process due to the reasons stated in the analysis of the data section, a total of 564 students were determined as the sample. Appropriate sampling method was preferred in sample selection. Demographic information related to the sample is given in Table 1.

Table 1. Demographic information related to the research sample

\begin{tabular}{llll}
\hline Variables & & $\mathbf{f}$ & $\mathbf{\%}$ \\
\hline \multirow{2}{*}{ Gender } & Female & 251 & 44.5 \\
& Male & 313 & 55.5 \\
\cline { 2 - 4 } Grade & 5 & 185 & 32.8 \\
& 6 & 135 & 23.9 \\
& 7 & 128 & 22.7 \\
\hline
\end{tabular}

When Table 1 is examined, it is seen that $55.5 \%$ of the students participating in the study are males and $44.5 \%$ are females. When analyzed by grade levels, fifth grade students make up $32.8 \%$ of participants, sixth graders make up $23.9 \%$, seventh graders make up $22.7 \%$ and eighth graders make up $20.6 \%$ of the total.

\section{Data Collection Tools}

The data of the research were obtained with two different data collection instruments. The first of these is the Self-Efficacy Scale regarding Science Learning developed by Yaman (2016). This scale was first developed by Kaptan \& Korkmaz (2001), then adapted by Yaman \& Yalçın (2005) for classroom teachers, and then revised by Yaman in 2016 in order to find out the self-efficacy perceptions of secondary school students. The scale consists of three subfactors. These factors are named as "individual success oriented self-efficacy", "performance oriented self-efficacy" and "result oriented self-efficacy" respectively. As a result of the reliability study conducted by Yaman (2016), the internal-consistency coefficient of the scale 
was determined as .83. For the reliability level of the data collected for this study, the Cronbach Alpha coefficient was examined and the internal consistency coefficient was found to be .86 . The coefficients of internal consistence at the end of the analysis to determine the reliability level of the sub-factors are as follows: $.75, .68$ and .57 . There are 17 items in the Likert type scale. The highest total score that can be obtained on the scale is 85 , and the lowest total score is 17 . The sample items of the scale are as follows: I think I have enough knowledge on physical science subjects; I consider myself very talented in physical science, I find myself more talented in physical science than my friends.

The second scale used in the study is the Adolescent Decision Making Scale (ADMS) adapted by Çolakkadığlu \& Güçray (2007). The original version of this scale was developed in 1989 by Mann, Harmoni and Power. Çolakkadığlu \& Güçray carried out the adaptation to Turkish, validity and reliability studies in 2007 . The scale consisting of five sub-factors aims to assess adolescents' decision making skills. As a result of the structure validity studies, these sub-factors are named as "self-esteem, prudence-selectivity, panic, avoidance of responsibility and Indifference". There are 30 items in the scale which is in four grading type. The structure validity of the scale was examined in two stages, applied to 1582 students in the first stage and 382 students in the second stage. It is stated that Cronbach Alpha values for each subfactor of the scale are $.79 ; .78 ; .77 ; .65$ and .73 . It is found that the reliability coefficients in this study are $.82 ; .80, .75, .70$, and .74 . The highest score that can be obtained on ADMS is 90 and the lowest score is 0 . Sample items of this scale are: I trust my decision-making ability, I prefer to leave the decisions to others, I do not like taking responsibility for decisionmaking.

\section{Data Analysis}

After the data obtained from the sample were transferred to a computer program, the reverse items were converted and descriptive analyzes were performed on the data. For this purpose, firstly, whether there are outliers in the dataset was checked. Since the scores of individuals with outliers in their answers have a high effect in factor solutions, it is recommended to delete them from the data file and thus to clear them from this error (Tabachnick \& Fidell, 2014). It was determined that there are 26 outliers in the data set of this research and these were removed. The authors stated that this does not have a significant impact on the results, since the loss data rate is less than 5\%. With the exclusion of these students from the data set, the number of samples decreased to 564 students. After this process, it was examined whether the data met the normality assumption. With these tests it was tested if the data came from a normally distributed universe and thusly if it had the generalizability feature. In light of the normality test performed with kurtosis and skewness tests, the data that appeared to have a normal distribution were analyzed by parametric analyzes. It was detected that the skewness and kurtosis values were between -1.00 and +1.00 for each variable. Also, Box's test results were used for the multi-way ANOVA and it was determined that the variances were equal. Pearson Moments Product Correlation Coefficient was used to determine the relationship between self-efficacy and decision-making skills. The collected data was intended to see whether there were differences between the groups as well as the relationships between the variables. In order to figure out the relationship between selfefficacy and decision-making skills, Pearson Product-Moment Correlation Coefficient was made use of. The collected data is for determining if there are differences between the groups as well as the relationships between the variables. The values obtained for the correlation analysis are classified as follows: Low relationship from .00 to .29; Medium from .30 to .69; High relationship from .70 to 1.00 (Büyüköztürk, 2006). Eta-square (effect size) value was 
also referred to for variance analysis. This analysis was carried out to determine to what extent the variable, whose effect was examined independently from the sample and the tests applied, existed in the research results (Field, 2005). The eta-square value obtained was interpreted according to the classification determined by Cohen (1988). The effect sizes were defined as small for $\eta 2 \leq .01$; medium for $.01<\eta 2 \leq .06$ and high for $.06<\eta 2 \leq 0.14$. One-way ANOVA analysis was performed to test the direction of the difference between the groups in the multi-way variance analysis, and the Scheffe test, one of the post-hoc analysis, was resorted to for the difference between the groups. The confidence interval for these analyzes was calculated as $95 \%$. Factorial variance analysis, where a dependent variable is examined according to two independent variables, was used in data analysis. By using factorial variance analysis, how the students' self-efficacy and decision-making skills were affected by gender and class variables was analyzed.

\section{Findings}

This section includes the findings out of the analysis of the data obtained from the sample. Descriptive statistics of the scores that students got from self-efficacy scale regarding science learning and also from adolescents decision making scale are given below.

Table 2. Descriptive statistical results of the average scores from the self-efficacy scale regarding science learning and from the adolescent decision-making scale

\begin{tabular}{llll}
\hline Variables & $\mathrm{N}$ & $\overline{\mathrm{X}}$ & $\mathrm{S}$ \\
\hline Factor 1. Self-efficacy regarding science learning & 564 & 3.53 & .69 \\
\hline Factor 1.1. Individual & 564 & 3.48 & .70 \\
Factor 1.2. Performance & 564 & 3.60 & .85 \\
Factor 1.3. Result & 564 & 3.53 & .88 \\
\hline Factor 2. Decision making & 564 & 1.42 & .32 \\
\hline Factor 2.1. Self-esteem & 564 & 1.73 & .48 \\
Factor 2.2 Prudence & 564 & 1.99 & .57 \\
Factor 2.3 Indifference & 564 & 1.33 & .56 \\
Factor 2.4. Panic & 564 & 1.04 & .60 \\
Factor 2.5. Avoidance of responsibility & 564 & 0.99 & .58 \\
\hline
\end{tabular}

As can be seen in Table 2, the average score of the participants on the Self-Efficacy Scale regarding Science Learning is 3.53 out of 5. This score indicates that students' self-efficacy perceptions are above average. The average scores that the students got from the sub-factors are also accepted as an indicator of their having self-efficacy perceptions above average for each sub-dimension. When the average scores of the students on the decision-making scale are examined, it is observed that the average of the decision-making score is 1.42 out of 3 points and this implies that the decision-making skill levels are below the average. When the sub-dimensions are studied, it is confirmed that the self-esteem and prudence levels of the students are above average and the tendencies of Indifference, panic and avoidance of responsibility are lower than average. Whether the total scores obtained from both scales show a significant difference according to the gender of the students is determined by the following analysis. 
Table 3. Results of independent samples t-test analysis of the total and sub dimension scores of the self-efficacy scale and decision-making scale according to students' gender

\begin{tabular}{|c|c|c|c|c|c|c|c|}
\hline Variables & Gender & $\mathrm{n}$ & $\overline{\mathrm{X}}$ & $\mathrm{S}$ & df & $\mathrm{t}$ & $\mathrm{p}$ \\
\hline \multirow{2}{*}{$\begin{array}{l}\text { Factor 1. Self-efficacy regarding science } \\
\text { learning }\end{array}$} & Girl & 251 & 3.58 & .66 & 562 & 1,53 & .128 \\
\hline & Boy & 313 & 3.49 & .71 & & & \\
\hline \multirow{2}{*}{ Factor 1.1. Individual } & Girl & 251 & 3.54 & .67 & 562 & 1,77 & .078 \\
\hline & Boy & 313 & 3.43 & .73 & & & \\
\hline \multirow{2}{*}{ Factor 1.2. Performance } & Girl & 251 & 3.68 & .81 & 562 & 1,72 & .086 \\
\hline & Boy & 313 & 3.55 & .87 & & & \\
\hline \multirow{2}{*}{ Factor 1.3. Result } & Girl & 251 & 3.52 & .88 & 562 & , 18 & .854 \\
\hline & Boy & 313 & 3.53 & .88 & & & \\
\hline \multirow{2}{*}{ Factor 2. Decision making } & Girl & 251 & 1.38 & .31 & 562 & 2,58 & .010 \\
\hline & Boy & 313 & 1.45 & .33 & & & \\
\hline \multirow{2}{*}{ Factor 2.1. Self-esteem } & Girl & 251 & 1.74 & .47 & 562 & ,74 & .460 \\
\hline & Boy & 313 & 1.72 & .48 & & & \\
\hline \multirow{2}{*}{ Factor 2.2. Prudence } & Girl & 251 & 2.03 & .56 & 562 & 1,31 & .192 \\
\hline & Boy & 313 & 1.97 & .57 & & & \\
\hline \multirow{2}{*}{ Factor 2.3. Indifference } & Girl & 251 & 1.31 & .54 & 562 & 1,01 & .313 \\
\hline & Boy & 313 & 1.35 & .58 & & & \\
\hline \multirow{2}{*}{ Factor 2.4. Panic } & Girl & 251 & .94 & .58 & 562 & 3,54 & .000 \\
\hline & Boy & 313 & 1.12 & .60 & & & \\
\hline \multirow{2}{*}{$\begin{array}{l}\text { Factor } 2.5 \text {. Avoidance of } \\
\text { responsibility }\end{array}$} & Girl & 251 & .88 & .56 & 562 & 4,51 & .000 \\
\hline & Boy & 313 & 1.92 & .58 & & & \\
\hline
\end{tabular}

When Table 3 is scrutinized, it is spotted that the students' self-efficacy average scores regarding science learning are close to each other according to their gender and there exists no statistically significant difference. The females' scores in self-efficacy total score and individual achievement and performance dimensions do not differ significantly and the males' scores in result oriented self-efficacy do not differ significantly but are partially high. It is found that the average scores of male students are higher than the female students in the total score of the decision-making scale and its sub-dimensions, panic and avoidance of responsibility sub-dimensions and the difference in points is statistically significant $(p<.05)$. Although it is diagnosed that the average scores of male students are higher than the scores of female students in the Indifference dimension of the decision-making scale and that the score of female students is higher than the score of male students in self-esteem and prudence dimensions, it is highlighted that the difference in points is not statistically significant. So as to delve into the differentiation of the scores of the participating students obtained from to the scales according to the grade level, the ANOVA analysis presented in the table below is performed.

Table 4. ANOVA analysis findings showing differentiation of average scores from the scales according to grade level

\begin{tabular}{lllllllllll}
\hline \multirow{2}{*}{ Variables } & Grade & $\mathrm{N}$ & $\overline{\mathrm{X}}$ & $\mathrm{S}$ & $\mathrm{SS}$ & $\mathrm{MS}$ & $\mathrm{sd}$ & $\mathrm{F}$ & $\mathrm{p}$ & Dif. \\
\cline { 2 - 10 } & 5th Grade & 185 & 3.67 & .72 & 10.04 & 3.34 & $3-560$ & 7.19 & .000 & $5-8$ \\
Factor 1. Self-efficacy & 6th Grade & 135 & 3.51 & .72 & & & & & & \\
regarding science learning & 7th Grade & 128 & 3.54 & .60 & & & & & & \\
& 8th Grade & 116 & 3.29 & .66 & & & & & & \\
& Total & 564 & 3.52 & .69 & & & & & & \\
\cline { 2 - 11 } & 5th Grade & 185 & 3.64 & .73 & 11.58 & 3.86 & $3-560$ & 8.08 & .000 & $5-8$ \\
Factor 1.1. Individual & 6th Grade & 135 & 3.44 & .73 & & & & & & \\
& 7th Grade & 128 & 3.48 & .63 & & & & & & \\
& 8th Grade & 116 & 3.25 & .64 & & & & & & \\
& Total & 564 & 3.48 & .70 & & & & & & \\
\cline { 2 - 10 }
\end{tabular}




\begin{tabular}{|c|c|c|c|c|c|c|c|c|c|c|}
\hline \\
\hline \multirow{5}{*}{$\begin{array}{l}\text { Factor 1.2. } \\
\text { Performance }\end{array}$} & 5th Grade & 185 & 3.68 & .85 & 4.45 & 1.48 & $3-560$ & 2.08 & .103 & \\
\hline & 6th Grade & 135 & 3.61 & .92 & & & & & & \\
\hline & 7th Grade & 128 & 3.63 & .73 & & & & & & \\
\hline & 8th Grade & 116 & 3.44 & .85 & & & & & & \\
\hline & Total & 564 & 3.60 & .85 & & & & & & \\
\hline \multirow{5}{*}{ Factor 1.3. Result } & 5th Grade & 185 & 3.71 & .92 & 19.04 & 6.35 & $3-560$ & 8.59 & .000 & $5-8$ \\
\hline & 6th Grade & 135 & 3.54 & .87 & & & & & & \\
\hline & 7th Grade & 128 & 3.53 & .71 & & & & & & \\
\hline & 8th Grade & 116 & 3.20 & .89 & & & & & & \\
\hline & Total & 564 & 3.52 & .88 & & & & & & \\
\hline \multirow{5}{*}{ 2. Decision making } & 5th Grade & 185 & 1.44 & .37 & .38 & .13 & $3-560$ & 1.21 & .312 & \\
\hline & 6th Grade & 135 & 1.37 & .31 & & & & & & \\
\hline & 7th Grade & 128 & 1.42 & .30 & & & & & & \\
\hline & 8th Grade & 116 & 1.43 & .28 & & & & & & \\
\hline & Total & 564 & 1.41 & .32 & & & & & & \\
\hline \multirow{5}{*}{ Factor 2.1. Self-esteem } & 5th Grade & 185 & 1.68 & .49 & 2.00 & .67 & $3-560$ & 2.96 & .031 & $8-5$ \\
\hline & 6th Grade & 135 & 1.69 & .49 & & & & & & \\
\hline & 7th Grade & 128 & 1.74 & .48 & & & & & & \\
\hline & 8th Grade & 116 & 1.83 & .42 & & & & & & \\
\hline & Total & 564 & 1.73 & .48 & & & & & & \\
\hline \multirow{5}{*}{ Factor 2.2. Prudence } & 5th Grade & 185 & 2.04 & .57 & 2.45 & .81 & $3-560$ & 2.56 & .054 & \\
\hline & 6th Grade & 135 & 1.88 & .59 & & & & & & \\
\hline & 7th Grade & 128 & 2.04 & .56 & & & & & & \\
\hline & 8th Grade & 116 & 1.97 & .52 & & & & & & \\
\hline & Total & 564 & 1.99 & .57 & & & & & & \\
\hline \multirow{5}{*}{$\begin{array}{l}\text { Factor } 2.3 . \\
\text { Indifference }\end{array}$} & 5th Grade & 185 & 1.34 & .56 & .24 & .08 & $3-560$ & .25 & .863 & \\
\hline & 6th Grade & 135 & 1.29 & .58 & & & & & & \\
\hline & 7th Grade & 128 & 1.35 & .56 & & & & & & \\
\hline & 8th Grade & 116 & 1.33 & .56 & & & & & & \\
\hline & Total & 564 & 1.33 & .56 & & & & & & \\
\hline \multirow{5}{*}{ Factor 2.4. Panic } & 5th Grade & 185 & 1.04 & .70 & .39 & .13 & $3-560$ & .36 & .782 & \\
\hline & 6th Grade & 135 & 1.07 & .59 & & & & & & \\
\hline & 7th Grade & 128 & 1.01 & .58 & & & & & & \\
\hline & 8th Grade & 116 & 1.01 & .46 & & & & & & \\
\hline & Total & 564 & 1.03 & .60 & & & & & & \\
\hline \multirow{5}{*}{$\begin{array}{l}\text { Factor 2.5. Avoidance } \\
\text { of responsibility }\end{array}$} & 5th Grade & 185 & 1.09 & .62 & 3.15 & 1.05 & $3-560$ & 3.13 & .021 & $5-8$ \\
\hline & 6th Grade & 135 & ,91 & ,53 & & & & & & \\
\hline & 7th Grade & 128 & ,95 & ,58 & & & & & & \\
\hline & 8th Grade & 116 & ,98 & ,56 & & & & & & \\
\hline & Total & 564 & ,99 & ,58 & & & & & & \\
\hline
\end{tabular}

When Table 4 is dwelled upon, it is discovered that the students' general self-efficacy beliefs create statistically significant differences according to their grade levels $(p<.05)$. It is determined that the differences are between the fifth and the eighth grades and took place in favor of the fifth grade. In general, when the averages of self-efficacy beliefs and subdimensions are examined, it is identified that the average scores at the fifth grade level are highest and those in the eighth grade are the lowest.

When the differentiation of the average scores obtained from the decision-making scale according to the grade level is examined, a significant difference between the grade levels in the sub-dimensions of self-esteem and avoidance of responsibility $(\mathrm{p}<.05)$ is revealed. While 8th grade students have the highest average score in the self-esteem sub-dimension, the students with the lowest score are fifth grade students. In the avoidance of responsibility subdimension, the highest average is in the fifth grades and the lowest average score is in the sixth grades. However, the significant difference is tracked down between the fifth and eighth grades. After the ANOVA analysis, post-hoc tests are conducted to determine which group 
favor the difference. To that end it is discerned that in self-esteem sub-dimension the difference is between the five and eighth grades and in favor of the eighth grades, and in avoidance of responsibility sub-dimension the difference is significant between five and eighth grades and in favor of fifth grades. The findings examining the effects of gender and class level on the students' self-efficacy decision making and self-efficacy average scores are shared in Table 5.

Table 5. Factorial variance analysis findings examining the effects of gender and class level on the students' self-efficacy decision making and self-efficacy average scores

\begin{tabular}{|c|c|c|c|c|c|c|c|}
\hline Variables & Impact & SS & $\mathrm{sd}$ & MS & $\mathrm{F}$ & $\mathrm{p}$ & $\eta 2$ \\
\hline \multirow{5}{*}{ Self-efficacy } & Gender & 1.66 & 1 & 1.66 & 3.69 & .055 & .007 \\
\hline & Grade & 8.79 & 3 & 2.93 & 6.50 & .000 & .034 \\
\hline & Gender*Grade & 6.01 & 3 & 4.44 & 4.44 & .004 & .023 \\
\hline & Error & 57.04 & 555 & .10 & & & \\
\hline & Total & 1194.10 & 563 & & & & \\
\hline \multirow{5}{*}{ Decision making } & Gender & .82 & 1 & .73 & 7.04 & .008 & .013 \\
\hline & Grade & .32 & 3 & .120 & 1.16 & .324 & .006 \\
\hline & Gender*Grade & .40 & 3 & .30 & 1.23 & .297 & .007 \\
\hline & Error & 250.35 & 555 & .45 & & & \\
\hline & Total & 7286.05 & 564 & & & & \\
\hline
\end{tabular}

When Table 5 is examined, the differentiation of students' decision making skills and selfefficacy perceptions according to gender, class and gender*class interaction was observed. The results obtained display that adolescents' decision-making skills are affected by the gender variable, and self-efficacy perception differs according to class and gender-class interaction $(p<.05)$. It was determined that the effect level of these variables on decisionmaking skills and self-efficacy perceptions is "small" $(\eta 2<.05)$. Büyüköztürk (2006) emphasizes that the eta-square value explains the magnitude of the effect of the independent variable on the dependent variable, and accentuates that this value varies between .00 and 1.00. Accordingly, $\eta 2$ values at .01, .06 and .14 levels are interpreted as "small", "medium" and "wide" effect size in the same order. The findings regarding the relationship between students' self-efficacy perceptions and their decision-making skills are given in Table 6.

Table 6. The relationship between secondary school students' self-efficacy perceptions of science learning and decision making skills

\begin{tabular}{llllllllll}
\hline Variables & 1. & 1.1 & 1.2 & 1.3 & 2 & 2.1 & 2.2 & 2.3 & 2.4 \\
\hline 1. Self-efficacy regarding science learning & & & & & & & & \\
Factor 1.1: Individual & $.94^{* *}$ & & & & & & & \\
Factor 1.2: Performance & $.88^{* *}$ & $.71^{* *}$ & & & & & & & \\
Factor 1.3: Result & $.80^{* *}$ & $.65^{* *}$ & $.63 * *$ & & & & & \\
2. Decision making & $.10^{*}$ & $.10^{*}$ & .08 & .07 & & & & \\
Factor 2.1. Self-esteem & .06 & .04 & .02 & $.11^{*}$ & $-.40^{*}$ & & & & \\
Factor 2.2: Prudence & $.28^{* *}$ & $.24^{* *}$ & $.28^{* *}$ & $.23^{* *}$ & $.37^{* *}$ & $.10^{*}$ & & & \\
Factor 2.3: Indifference & .05 & .06 & .04 & -.02 & $.69^{* *}$ & .00 & $.11^{* *}$ & & \\
Factor 2.4: Panic & .04 & -.04 & -.03 & -.01 & $.69^{* *}$ & $.12^{* *}$ & -.08 & $.36^{* *}$ & \\
Factor 2.5: Avoidance of responsibility & -.06 & -.03 & -.07 & -.08 & $.72^{* *}$ & $.09^{*}$ & -.06 & $.47^{* *}$ & $.53^{* *}$ \\
\hline
\end{tabular}

When Table 6 is explored, it is diagnosticated that there is a significant and high-level relationship between the self-efficacy perception for science learning and the sub-dimensions of the scale. That being said, the relationship between total score of self-efficacy belief regarding science learning and total scores of decision making $(r=.07)$ is weak. When the relationship between the scores obtained by the participants from the sub-dimensions of the decision-making scale and their self-efficacy perceptions regarding science learning is 
investigated, it is monitored that there is a weak and significant relationship between the selfesteem sub-dimension and there is no significant relationship between the other subdimensions. It is noticed that there are positive and significant relationships between the subdimensions of the self-efficacy scale regarding science learning (individual self-efficacy, performance-oriented self-efficacy and result-oriented self-efficacy), and prudent selectivity, which is the sub-dimension of adolescent decision-making scale.

\section{Discussion}

Individuals routinely use their decision making processes in their daily lives. Decision making is a process that includes plentiful sub-dimensions and requires the existence of plenty of competencies. According to Evans (1990), decision making is not an inherent skill, but a status of competence that develops based on experience over time and differs in every individual. The concept of self-efficacy is defined as people's beliefs regarding the competencies they have in dealing with a situation (Bandura, 1997). The decision-making skills that individuals use to solve a problem are affected by their self-efficacy beliefs. In other words, it can be pronounced that an individual who has a high self-efficacy belief that can take an action with their effective decision-making skills, to put it in a different way, there is a relationship between this belief and skill. In relation to the results obtained in this research, it is determined that there is a statistically significant relationship between the selfefficacy perceptions of secondary school students regarding science learning and their decision making skills.

When the self-efficacy scores are examined depending on gender, it is found that the selfefficacy belief levels of female students are higher than male students, nonetheless, this difference is not significant. Koç \& Arslan (2017), in their studies which they examined the academic self-efficacy of primary school second grade students, concluded that self-efficacy perceptions of female students are higher than those of male students. The results obtained in this study are in parallel with the study of Koç \& Arslan. With that being said, in the literature, it is seen that self-efficacy perception does not vary according to gender in numerous studies and in some others (Demirtaş, Cömert, \& Özer, 2011; Durdukoca, 2010; Iş̧ksal \& Aşkar, 2012; Korkut \& Babaoğlan, 2012) male students have higher self-efficacy perceptions. Considering the results of this study and other studies in the literature, it can be declared that the self-efficacy perception has the potential to produce different results in terms of gender within the context of sampling or education level. When these two independent variables are considered together, it is concluded that the students' grade levels and classgender interactions impose a significant difference on their self-efficacy perceptions. It is verified that these differences are between the fifth and eighth grades and the difference is in favor of the fifth grades. It can be argued that the reason for this difference is owing to the high stakes national examination administered for entrance to high school in the eighth grade. Bandura (1977) underlined that besides performance, learning from others, encouragement or persuasion, anxiety as a negative arousal have effects on individuals' self-efficacy expectations. Since the exam is also an important source of anxiety, it may have had an impact on students' self-efficacy levels at the time of the study. When the literature is examined, there are results about a positive relationship between self-efficacy and anxiety (Dadand1, Kalyon, \& Yazıc1, 2016). It is considered that in this study the difference in selfefficacy perception depending on class levels is because of this very reason. 


\section{Conclusion}

One of the results obtained in the study is that students have decision-making skills below the average level. In the science curriculum, it is stressed that decision-making skills are important with respect to raising science literate individuals. In this context, it can be expressed that the development of decision making skills that can be considered as low is of utmost importance as regards accomplishing science teaching goals. Karataş Memiş, Bozkurt, Cevizci, Avun, \& Öğretmen (2016), in their study, enunciated a remarkable result that there is a slightly negative relationship between science literacy and decision making skills. When decision making skills are examined by gender, it is conceived that there is a significant difference and this difference is in favor of females. Kuzgun (1992) found that the female students' indecision scores are higher than those of male students in the study for which he examined male and female students' decision making strategies. The results of the study are consistent with the results of this research. What is more, although it is observed that there is a difference in favor of females in the whole scale, it is found that there are significant differences in favor of male students in the sub-dimensions (panic and avoidance of responsibility). It is concluded that class level and class-gender interaction are not an effective variable on decision-making skills.

When the relationship between the variables discussed in the study are looked into, a high level of positive correlation is found between overall scores of belief regarding science learning and its sub-factors. It is ascertained that there is a great relationship especially between individual achievement and overall score. Even though there is a great relationship between self-efficacy belief sub-factors, it is evidenced that the lowest relationship, compared to others, is between expectation of result and performance oriented self-efficacy. This unveils that the students' self-efficacy beliefs and sub-factors are related to each other and generally give results like a single variable. In other words, it can be claimed that taking action for a single factor to boost the self-efficacy beliefs of students can contribute to the increase in other factors.

Contrary to self-efficacy belief, the relationship between general scores regarding decisionmaking skills and sub-factors or relationship between sub-factors are determined not to have a certain direction or power. It is measured that the relationship between the general score of this skill and the score of the avoidance of responsibility sub-factor is highest and the relationship between the general score of this skill and the self-esteem sub-factories are at the lowest level. It is pinpointed that there is a very low negative relationship between prudence sub-factor of decision-making and sub-factors of panic and avoidance responsibility, and there is no relation between Indifference and self-esteem factors. The most striking result regarding the decision-making dimension is that there is a moderate negative relationship between general decision-making score and self-esteem. These findings show that the relationship between sub-factors and other sub-factors does not have a certain direction and power alongside the general scores and sub-factors of decision-making skills. As it can be understood from here, separate actions should be taken for each sub-dimension in order to both evaluate and improve decision making skills. Based on these results, it is recommended to conduct separate activities for each sub-dimension in future studies to be carried out to enhance their decision making skills.

When the results of the study are evaluated in general, it is determined that there is a relationship between self-efficacy perception for science learning and adolescent decisionmaking skills, and when evaluated in terms of gender, the results point to a general difference 
in favor of female students. In compliance with these results, it can be thought that it will be useful to produce and implement projects that include activities in which students will use their decision-making skills in order to increase their self-efficacy perceptions of science learning.

The study can be repeated with different independent variables from the independent variables in this study. The sample group in this study consists of secondary school students. It can later be applied to high school or university level students in other studies.

It is believed that this study, which sheds light on the relationship between decision-making and self-efficacy belief in respect of different variables and the relationship between them, offers results of crucial importance for the development of interventions enabling positive practices. It can be said that one of the effective ways to determine to what extent these two variables change together might be longitudinal survey studies. For this, the self-efficacy beliefs and decision-making skills of students who have recently registered to secondary school can be assessed for four consecutive years. Different school types, regions and socioeconomic levels can also be taken into account as variables for this four-year data collection.

\section{Acknowledgement}

A part of this study was presented as an oral presemtation at IASSR (International Association of Social Science Research) 2017.

\section{References}

Altunçekiç, A., Yaman, S., \& Koray, Ö. (2005). The research on prospective teachers' selfefficacy belief level and problem-solving skills. Kastamonu Education Journal, 13, 93-102.

Alver, B. (2005). The emphatic skills and decision-making strategies of the students of the department of guidance and psychological counselling, faculty of education were studied. Muğla University Journal of Social Sciences and Humanities Researches, 14, 19-34.

Avşaroğlu, S., \& Üre, Ö. (2007). The study of styles of coping with stress, decision-making and self-esteem of university students on decision-making in terms of self-esteem and some variables. Selçuk University the Journal of Institute of Social Sciences, 18, 85100 .

Bandura, A. (1977). Self-efficacy: Toward a unifying theory of behavioural change. Psychological Review, 84, 191-215.

Bandura, A. (1997). Self-efficacy: The exercise of control. Newyork: Freeman.

Betz, N. E., Klein, K. L., \& Taylor, K. M. (1996). Evaluation of a short form of the career decision-making self-efficacy scale. Journal of Career Assessment, 4(1), 47-57.

Beyth-Marom, R., Fischhoff, B., Quadrel, M. J., \& Furby, L. (1991). Teaching decision making to adolescents: A critical review. Teaching decision making to adolescents, pp. 19-59, Routledge: Taylor\& Francis.

Büyüköztürk, Ş. (2006), Data analysis handbook for social sciences ( $6^{\text {th }}$ edition). Ankara: Pegem A Publishing.

Caymaz, B. (2008). Prospective science and classroom teachers' self-efficacy beliefs about scientific literacy. Unpublished Master Thesis, Hacettepe University Intsitute of Social Sciences, Ankara. 
Cohen, J. (1988). The effect size index: D. In J. Cohen (Ed.), Statistical power analysis for the behavioral sciences (Vol. 2, pp. 284 -288). Mahwah, NJ: Erlbaum.

Çolakkadıŏglu, O. (2012). The reliability and validity study of adolescent decision making questionnaire for the high school students. Mustafa Kemal University Journal of Social Sciences Institute, 9(19), 387-403.

Çolakkadığlu, O., \& Güçray, S. S. (2007). The adaptation of adolescent decisionmaking questionnaire into Turkish. Eurasian Journal of Educational Research (EJER), 11(26), 61-71.

Dadand1, İ., Kalyon, A., \& Yazıc1, H. (2016). Teacher self-efficacy beliefs, concerns and attitudes towards teaching profession of faculty of education and pedagogical formation students. Bayburt Faculty of Education Journal 11(1), 253-269.

Demirtaş, H., Cömert, M., \& Özer, N. (2011). Pre-service teachers' self-efficacy beliefs and attitudes towards profession. Education and Science, 36(159), 96-111.

Deniz, M. E. (2004). Investigation of the relation between decision making self-esteem, decision making style and problem-solving skills of university students. Eurasian Journal of Educational Research, 15(13), 23-35.

Durdukoca, Ş. F. (2010). Analysis of academic self-efficiency beliefs of elementary school teacher candidates using different variables. Abant Izzet Baysal University Journal, 10(1), 69-77.

Emhan, A. (2007). Decision making process and using data processing systems. Electronic Social Sciences Journal, 6(21), 212-224.

Ergül, H. (2006). Motivation that affects academic achievement in online education structures, The Turkish Online Journal of Educational Technology - TOJET, 5(1), 124-128.

Evans, D. (1990). Problems in decision making process: A review. Longman Group UK Ltd. Intensive Care Nursing, 6,179-184.

Feinstein, N. (2011). Salvaging science literacy. Science Education, 95(1), 168-185.

Forbes, D. P. (2005). The effects of strategic decision making on entrepreneurial selfefficacy. Entrepreneurship theory and practice, 29(5), 599-626.

Furby, L., \& Beyth-Marom, R. (1992). Risk taking in adolescence: A decision-making perspective. Developmental review, 12(1), 1-44.

Işıksal, M., \& Aşkar, P. (2003). The scales of perceived mathematics and computer selfefficacy for elementary students, Hacettepe University, Faculty of Education Journal, 25, 109-118.

Karasar, N. (2012). Scientific research methodology, Ankara, Turkey: Nobel.

Kaptan, F., \& Korkmaz, H. (2001). The effect of collaborative science teaching on pre-service teachers' self-efficacy levels. V. Science Education Congress, Ankara: National Education Press.

Kaptan, F. (1999). Science teaching in primary education, İstanbul: National Education Press.

Karataş Memiş, E., Bozkurt, R., Cevizci, E., Avun, F., \& Öğretmen, B. (2016). Examination of decision-making strategy and scientific literacy of university students in terms of different variances. Cumhuriyet International Journal of Education, 5(4), 16-30.

Kavak, N., Tufan, Y., \& Demirelli, H. (2006). Science and technology literacy and informal science education: Potential role of newspapers. Gazi University Gazi Faculty of Education Journal, 26(3), 17-28.

Koç, C., \& Arslan, A. (2017). Academic self-efficacy perceptions and metacognitive awareness of reading strategies of secondary school students. Yüzüncü Yıl Üniversity Journal of Education, 14(1), 745-778.

Korkut, K., \& Babaoğlan, E. (2012). Primary school teachers' self-fficacy. International Journal of Management Economics and Business, 8(16), 269-281. 
Kuzgun, Y (1992). Decision strategies scale: Development and standardization. VII. Scientific Studies of the National Congress of Psychology. (Ed.) Bayraktar, R., \& Dağ, İ., P., Publication of Turkish Psychological Association, 161-170

Ministry of National Education [MNE]. (2018, 07 May). Science course (3, 4, 5, 6, 7 and 8th grades) curriculum. Retrieved fromhttp://mufredat.meb.gov.tr/Programlar.aspx

Narangerel, E. O. (2020). The mediation role of self-efficacy in decision making on the relationship between workload and work control and decision-making styles. Unpublished Master Thesis, Social Sciences Institute, Hacettepe University, Ankara.

Norfolk, D. (1989). Stress in work life. (Translated by: Leyla, Serdaroğlu). İstanbul: Form Publishing.

Norris, S. P., \& Phillips, L. M. (2003). How literacy in its fundamental sense is central to scientific literacy. Science education, 87(2), 224-240.

Saracaloğlu, A. S., Yenice, N., \& Özden, B. (2013). An analysis of the relationship between the prospective science, social Sciences and classroom teachers' self-efficacy perceptions and focus of academic control. Pamukkale University Faculty of Education Journal, 34(2), 227-250.

Tabachnick, B. G., \& Fidell, L. S. (2014). Using multivariate statistics. Harlow. Essex: Pearson Education Limited.

Tan, M., \& Temiz, A. (2003). The importance and role of the science process skills in science teaching. Pamukkale University Faculty of Education Journal, 13, 89-101.

Von Winterfeldt, D., \& Edwards, W. (1986). Decision analysis and behavioural research. Cambridge: Cambridge University Press.

Yaman, S. (2016). Adapting of science learning self-efficacy belief scale for middle school students: validity and reliability study. Inonu University Journal of the Faculty of Education, 17(2), 123-140.

Yaman, S., \& Yalçın, N. (2005). Effectiveness of problem-based learning approach on development of problem solving and self-efficacy beliefs levels in science education. Hacettepe University Journal of Education, 29, 229-236.

Yıldırım, F., \& İlhan, İ. Ö. (2010). The validity and reliability of the general self-efficacy scale-Turkish form. Turkish Journal of Psychiatry, 21(4), 301-308. 